\title{
Investigation of metallic nanoparticles adsorbed on the QCM sensor by SEM and AFM techniques
}

\author{
IOAN ALIN BUCURICA ${ }^{1,2, *} \mathbb{D}$, ION V POPESCU ${ }^{3,4} \mathbb{D}$, CRISTIANA RADULESCU $^{1,3} \mathbb{D}$, \\ GHEORGHE VALERICA CIMPOCA ${ }^{4}$, IOANA-DANIELA DULAMA ${ }^{1}$ (D, \\ SOFIA TEODORESCU ${ }^{1}$ D, ION VALENTIN GURGU ${ }^{1}$ D and DORIN DACIAN LET ${ }^{1}$ D \\ ${ }^{1}$ Institute of Multidisciplinary Research for Science and Technology, Valahia University of Targoviste, 130004 Târgovişte, \\ Romania \\ ${ }^{2}$ Doctoral School, Faculty of Physics, University of Bucharest, 050107 Bucharest, Romania \\ ${ }^{3}$ Faculty of Sciences and Arts, Valahia University of Targoviste, 130004 Târgovişte, Romania \\ ${ }^{4}$ Academy of Romanian Scientists, 050094 Bucharest, Romania \\ *Author for correspondence (bucurica_alin@yahoo.com)
}

MS received 30 June 2017; accepted 28 October 2017; published online 17 May 2018

\begin{abstract}
Quartz crystal microbalance (QCM) is known as a very sensitive device used for determination of mass quantity adsorbed on sensor surface. Its detection limits are in the range of $\mathrm{n} \mathrm{cm}^{-2}$. The adsorption mechanism of metallic nanoparticles on QCM sensor was investigated by scanning electron microscopy (SEM) and atomic force microscopy (AFM). This study aims to highlight the importance of QCM applications in nanoparticles deposition field. The layers formed through adsorption process, induced by the oscillations of the QCM sensor, were investigated by AFM for surface topography and for particle mean size values. The morphology of layers and nanoparticles dimensions were determined by SEM. For a more complex investigation of the nanoparticles adsorption mechanism, the chemical composition of layers was achieved using SEM coupled with energy dispersive X-ray spectrometer (SEM-EDS). This preliminary research involved a new approach in characterization of metallic nanoparticles layers to achieve functional assembled monolayers.
\end{abstract}

Keywords. Metallic nanoparticles; QCM; AFM; SEM; SEM-EDS.

\section{Introduction}

Nanoparticles are currently used in many fields, including medicine, manufacturing, materials, optical, environment, energy and electronics. The scientific interest concerning nanoparticles is given by the fact that it represents a bridge between bulk materials and atomic/molecular structures. In medical field, the nanoparticles are widely used to treat different tumours. Thus, the brain tumours and leukaemia as well can be treated using the chemotherapy drugs attached to carbon nanoparticles named nanodiamonds [1-4]. Today there is a large array of nanodiamonds for biomedical applications, especially due to their excellent optical properties and non-toxicity, as well. In other research [5], four iron-oxide nanoparticle systems were already tested as tool for targeting cancer cells. Recently, Gowda et al [6] have developed nanoparticles to deliver a melanoma-fighting drug directly to tumoural areas. For the growth of the bone around dental or joint implants, new nanodiamonds along with attached protein molecules were found [7-9]. The wide range of potential applications of nanoparticles continues to drive research in all fields forward. Recently, Phan et al [5] have exploited iron/iron oxide core/shell nanoparticle systems for nanomedicine applications due to the combination of high magnetization of the core (iron) and the chemical stability of the shell $\left(\mathrm{Fe}_{3} \mathrm{O}_{4}\right.$ or $\left.\gamma-\mathrm{Fe}_{2} \mathrm{O}_{3}\right)$, which confer better properties than either material alone. Last research [10] presents new synthetic skin, an innovative composite consisted of nickel nanoparticles and polymer, which is widely used in prosthetics, demonstrating a good self-healing capability. Other researches sustain that protein-filled nanoparticles may be used in inhalable vaccines [11,12] and polymeric micelle nanoparticles were already obtained to deliver drugs to different tumours [13-15]. One of the most promising studies [16] demonstrated that cerium oxide nanoparticles act as a good antioxidant to remove the undesired oxygen free radicals present in a bloodstream of the patients, as a result of a traumatic injury. In environmental field, the most known applications of nanoparticles are the ones to clean arsenic from water wells [17], to clean-up carbon tetrachloride pollution in groundwater [18] and to destroy the volatile organic compounds (VOCs) from air (i.e., when gold nanoparticles are embedded in a porous manganese oxide to play a catalyst role) $[19,20]$. Recently, there was an intense interest regarding textile odour-resistants. In this respect, silver nanoparticles were used in clothing to kill bacteria [21] and zinc oxide nanoparticles were dispersed in textile coatings to protect fibres from exposure to UV rays [22-24]. Several nanoparticle 
applications in energy and electronics fields are developed. Thus, the latest researches [25,26] have demonstrated that sunlight concentrated on different nanoparticles can produce steam with high energy efficiency, and the system was named solar steam device. Copper nanoparticles were used in space missions [27] and in solar cells manufacturing [28-31]. A new transistor known as a nanoparticle organic memory field-effect transistor (NOMFET) [32] was achieved. This transistor contains gold nanoparticles combined with organic molecules and can function in a similar way to synapses in the nervous system. Likewise, the palladium nanoparticles are already used in a hydrogen sensor [33,34]. Platinum-cobalt nanoparticles [35,36] as well as carbon nanoparticles [37] are being developed for fuel cells. The process of spoiling or drying out of food can be performed by using silica nanoparticles, which provide a barrier for oxygen and moisture in a plastic material used for packaging [38].

The quartz crystal microbalance (QCM) technique was used in various studies regarding the adsorption mechanism of nanoparticles on sensors [39-43]. The dynamic and dissipation modes of QCM were used to detect bacteria using gold nanoparticles [39] and to determine the mechanisms of nanoparticle monolayer formation (e.g., gold nanoparticles on poly(allylamine hydrochloride) [40], titanium dioxide nanoparticles [41], carbon-based nanoparticles [42] or gold nanoparticles [43]).

It is well known that nanoparticles in various media (i.e., gas and liquid phases) can be agglomerated (i.e., physically) and aggregated (i.e., chemically-bounded) [44]. In liquid phase (i.e., aqueous or organic), it is very difficult to obtain the homogeneous layers of nanoparticles and equivalent sizes of them. As aggregates, nanoparticles appear as clusters, which can be achieved by chemical reaction, sintering, surface growth and fragmentation. In this case, strong chemical bonds occur in clusters and the applications of these in different fields increase (e.g., catalysts, drugs, component in electronic devices, such as batteries, sensors, etc.) Between nanoparticles, agglomerations are occurring at low forces and for this reason, these can be easily destroyed by ultrasonication, stretching, fluid dispersion, or capillary condensation.

The novelty of this research is to obtain the homogeneous layers as a result of QCM oscillation frequency ( $5 \mathrm{MHz})$, also known as 'ultrasonic effect'. This effect prevents the massive agglomerations of nanoparticles and, at the same time, accelerates the polar solvent evaporation. Related to the scientific literature $[45,46]$, in which different techniques were used for sensor surface improvement (e.g., non-polar organic substances), this method used sensors without supplementary organic coating, which could lead to molecular aggregates with potential risk for medical or pharmaceutical fields.

In this respect, the obtained agglomerations were characterized by two techniques: atomic force microscopy (AFM) and scanning electron microscopy (SEM). By using these analytical methods, it was possible to determine the sizes of studied nanoparticles in colloidal solutions and the shape of the agglomerations. Finally, it was observed that according to the size and nature of nanoparticles, the shape is completely different. This study involves, besides the size and shape analysis of studied nanoparticles, and a carefully layer characterization of metallic nanoparticles to achieve functional assembled monolayers, which can be used in different applications (e.g., pharmaceuticals, medicine, agriculture, food safety, electronics, etc.).

\section{Materials and methods}

For this study, five colloidal solutions were analysed containing metallic nanoparticles from Particular GmBH. According to certificates, the samples were electrostatically stabilized and had the following concentrations: $\mathrm{Au}\left(22 \mathrm{mg} \mathrm{l}^{-1}\right)$, Ag $\left(17 \mathrm{mg} \mathrm{l}^{-1}\right), \mathrm{Pd}\left(25 \mathrm{mg} \mathrm{l}^{-1}\right)$, Ti $\left(18 \mathrm{mg} \mathrm{l}^{-1}\right)$ and $\mathrm{Fe}$ $\left(21 \mathrm{mg} \mathrm{l}^{-1}\right)$. To remove the water from solutions and to achieve uniform adsorption, it was used as a QCM (QCM-200, Stanford Research Instruments) along with Ti-Pt sensors.

QCM is a very sensitive device, capable to measure mass variations in the range of $\mathrm{ng} \mathrm{cm}^{-2}$ [47-51]. Sauerbrey [52] has developed an equation, which is used to correlate the frequency shift of a piezoelectric crystal with the mass variation equation (1):

$$
\Delta f=-\frac{2 f_{0}^{2}}{A \sqrt{\rho_{\mathrm{q}} \mu_{\mathrm{q}}}} \Delta m,
$$

where $\Delta f$, frequency shift $(\mathrm{Hz}) ; f_{0}$, resonant frequency $(\mathrm{Hz}$; $A$, active crystal area $\left(\mathrm{cm}^{2}\right) ; \rho_{\mathrm{q}}$, density of quartz $\left(\rho_{\mathrm{q}}=\right.$ $\left.2.648 \mathrm{~g} \mathrm{~cm}^{-3}\right) ; \mu_{\mathrm{q}}$, shear modulus of quartz for AT-cut crystal $\left(\mu_{\mathrm{q}}=2.947 \times 10^{11} \mathrm{~g} \mathrm{~cm}^{-1} \mathrm{~s}^{-2}\right) ; \Delta m$, mass variation $(\mathrm{g})$.

Quartz sensors covered by titanium-platinum (TiPt) layer with a frequency of $5 \mathrm{MHz}$ were purchased from Stanford Research Systems. Before applying colloidal sample, the sensors were cleaned in Piranha solution, a mixture of hydrogen peroxide $\left(30 \% \mathrm{H}_{2} \mathrm{O}_{2}\right.$, Merck) and sulphuric acid (95\% $\mathrm{H}_{2} \mathrm{SO}_{4}$, Merck) with volume ratio 1:3 for $3 \mathrm{~min}$. Then, sensors were immersed in deionized water (Milli-Q Water System Millipore) for $15 \mathrm{~min}$ and dried out in a gentle flow of nitrogen gas.

After intern calibration of QCM-200 system and resonance frequency determination of unload sensor, $f_{\mathrm{i}}$ (figure 1a) was complete, a $0.5 \mathrm{ml}$ of sample was applied directly over the sensor surface in static mode. Four hours later, during which the water was removed (figure $1 \mathrm{~b}$ ), the sensor frequency, $f_{\mathrm{f}}$ was recorded and on its bases, the frequency shift was calculated.

The sensors containing adsorbed nanoparticles were investigated in first instance by NT-MDT Ntegra Prima AFM (figure 2). For topography, it was chosen at the very start, the contact AFM mode along with high resolution contact 'golden' Silicon Cantilevers CSG10, made by single crystal silicon and doped with antimony. These AFM probes are three times better than uncoated ones and the base being doped as it avoids the electrostatic charges $[53,54]$. 


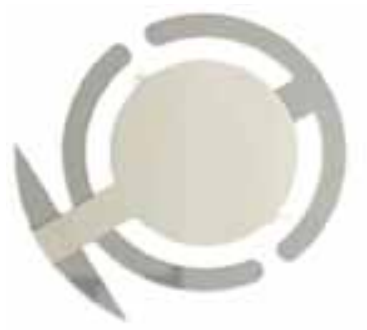

a

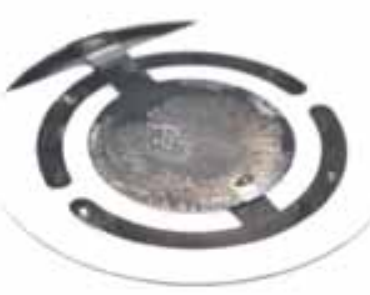

b

Figure 1. QCM sensor (a) before and (b) after adsorption process.

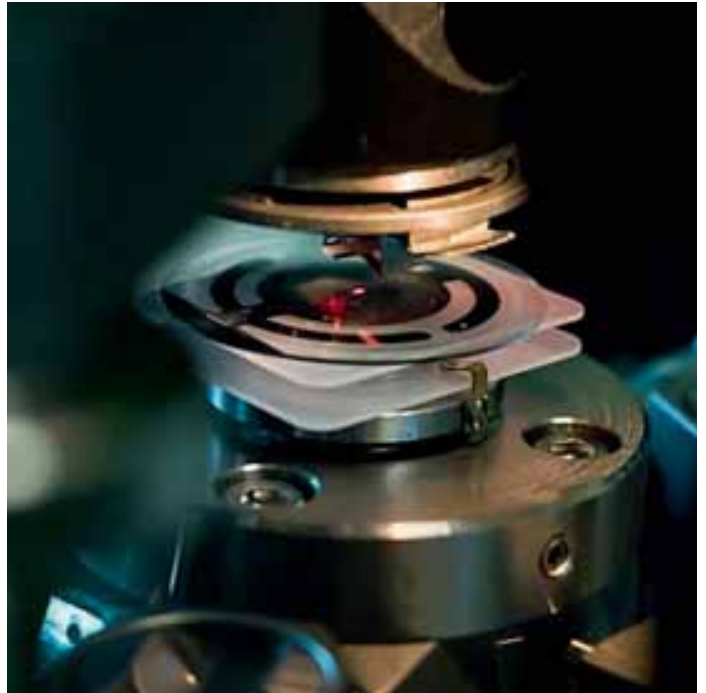

Figure 2. AFM investigation sequence.

Later on, the sensors were passed to Hitachi SU-70 SEM coupled with UltraDry energy dispersive spectrometer (EDS) by Thermo Scientific, for further analyses. The SEM is field emission (FE-SEM) type which operates under high vacuum $\left(10^{-8} \mathrm{~Pa}\right)$, and offers $1 \mathrm{~nm}$ resolution at $15 \mathrm{kV}$ acceleration voltage [55-58]. SEM investigations were performed under $10 \mathrm{kV}$ accelerating voltage and 8-17 mm working distance range. Colloidal nanoparticles samples were also analysed using EDS to detect some possible impurities

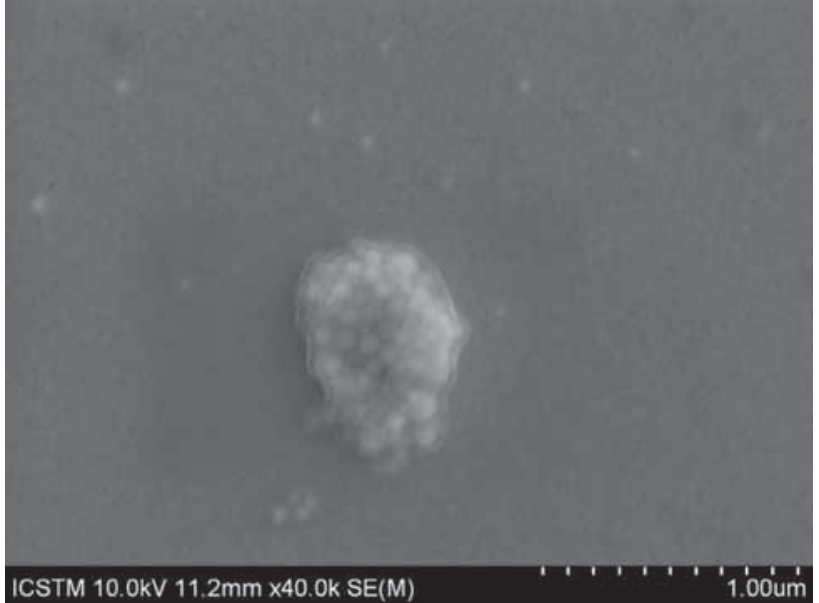

Figure 3. SEM image of Pd-agglomerated nanoparticles on thin layer.

occurred during the adsorption process of nanoparticles on the sensors.

\section{Results and discussion}

The nanoparticles adsorption on the QCM sensor was investigated, using five colloidal solutions (i.e., hydrocolloids). These solutions were chosen for physico-chemical characterization using complementary analytical techniques such as AFM and SEM. The morphology and topography of the

Table 1. Mass of nanoparticles adsorbed on QCM sensor surface.

\begin{tabular}{lccccc}
\hline & $f_{\mathrm{i}}(\mathrm{Hz})$ & $f_{\mathrm{f}}(\mathrm{Hz})$ & $\Delta f(\mathrm{~Hz})$ & $C_{\mathrm{f}}\left(\mathrm{Hz} \mu \mathrm{g}^{-1} \mathrm{~cm}^{2}\right)$ & $\Delta m\left(\mu \mathrm{g} \mathrm{cm}^{-2}\right)$ \\
\hline Fe NP & 5023579 & 5023144 & -435 & -56.6 & 7.69 \\
Ti NP & 5033900 & 5033529 & -371 & & 6.55 \\
Ag NP & 5027735 & 5027392 & -343 & & 6.06 \\
Au NP & 5025611 & 5025157 & -454 & & 8.02 \\
Pd NP & 5032135 & 5031619 & -516 & & 9.11 \\
\hline
\end{tabular}

$f_{\mathrm{i}}$, frequency of unload sensor; $f_{\mathrm{f}}$, frequency of sensor after metallic nanoparticles adsorption; $\Delta f$, frequency shift $\left(f-f_{\mathrm{f}}\right) ; C_{\mathrm{f}}$, sensibility factor of the AT-cut sensor at room temperature; and $\Delta m$, mass of nanoparticles adsorbed on sensor surface. 


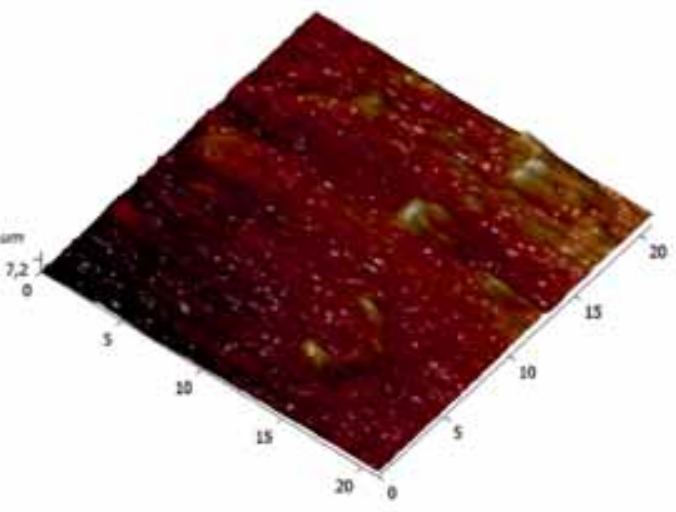

a

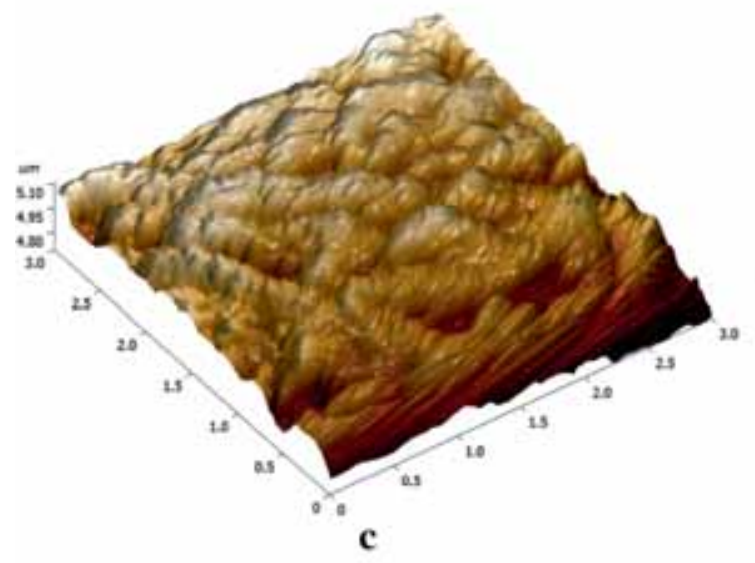

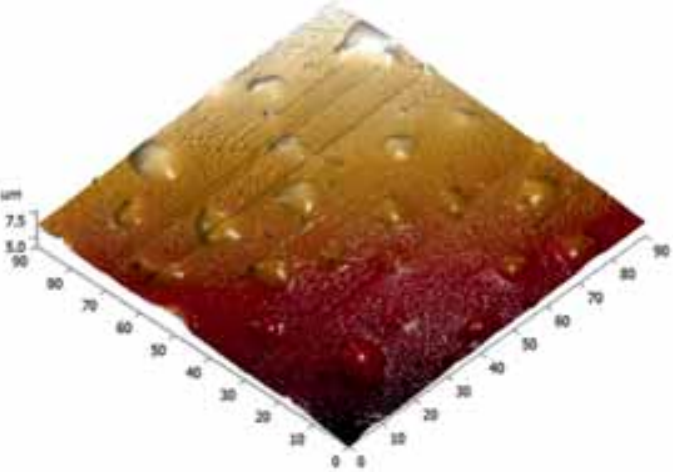

b

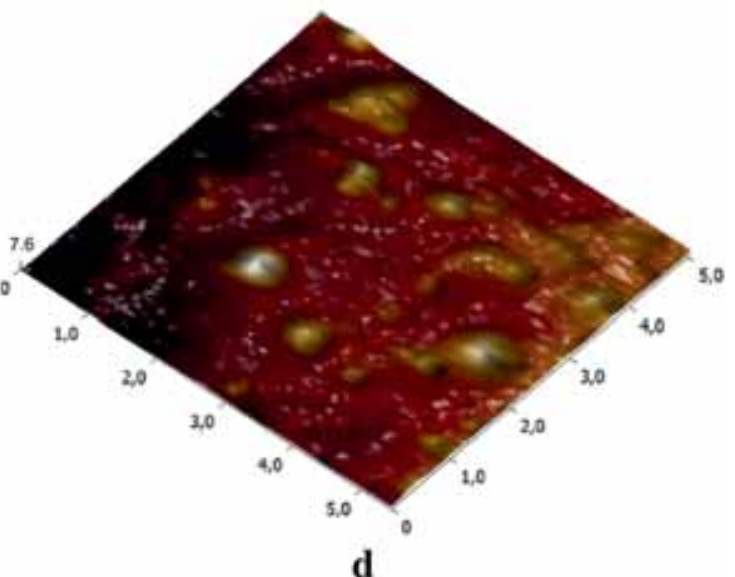

d

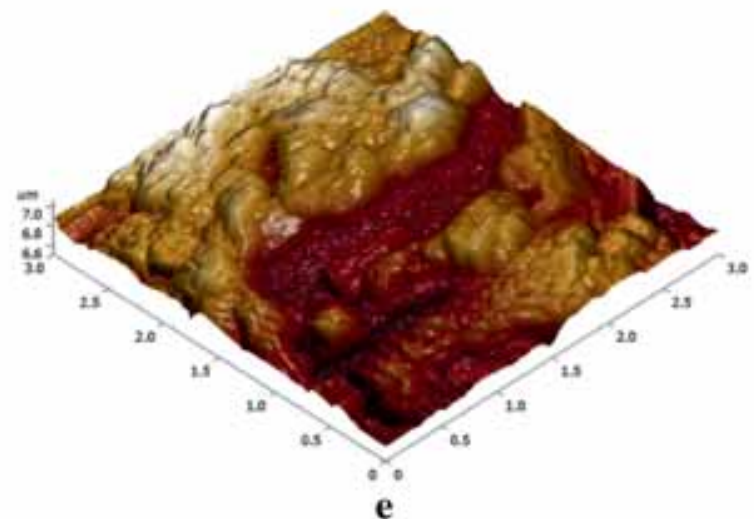

Figure 4. AFM 3D topography images for several agglomerated nanoparticles: (a) Ti; (b) Fe; (c) Pd; (d) $\mathrm{Ag}$ and (e) Au.

deposed layers were observed by both the techniques. In this respect, TiPt sensors with $1.37 \mathrm{~cm}^{2}$ active area and $5 \mathrm{MHz}$ resonant frequency were used, and thus, the Sauerbrey equation (1) is reduced to:

$$
\Delta m=\Delta f /-C_{\mathrm{f}},
$$

where $C_{\mathrm{f}}$ represent the sensibility factor of the AT-cut sensor

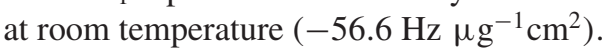

Based on equation (2), the mass shift for each studied metallic nanoparticles is calculated (table 1).

All five QCM sensors showed similarities concerning adsorption mechanism. Nanoparticles were adsorbed uniformly over the entire sensor, but some investigated areas were observed with different sort of agglomerations (e.g., Pd nanoparticles, figure 3). On the layer level, these agglomerations are reduced as number, but spread on the surface of QCM sensor (figures 3-5). 

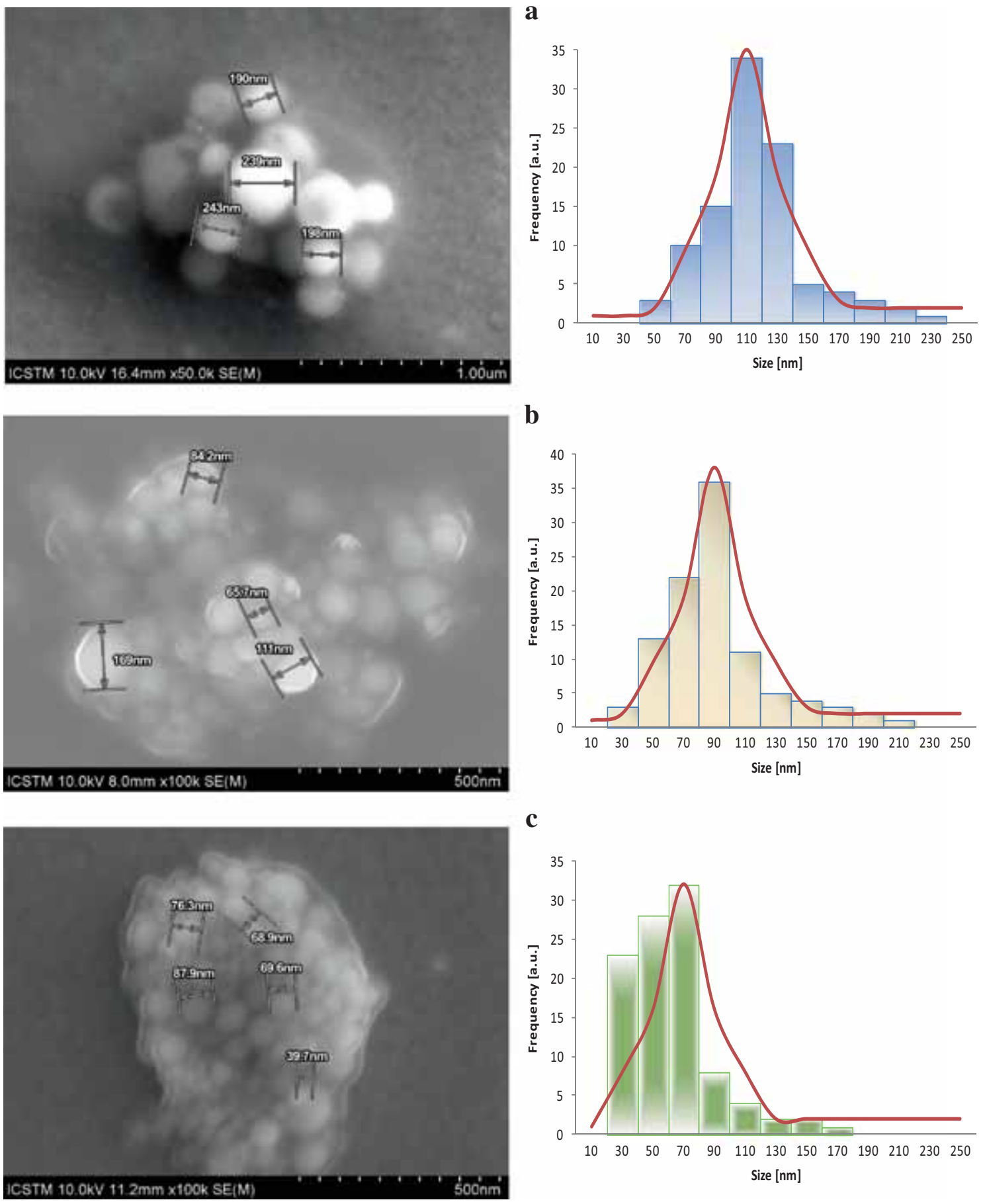

Figure 5. SEM images and size histogram of nanoparticles: (a) Ti; (b) Fe; (c) Pd; (d) Ag; and (e) Au.

Depending on the type and size of nanoparticles, the agglomerations show different shapes and these can be seen mainly by AFM (figure 4).

These agglomeration shapes were investigated to determine the mean size of nanoparticles. In this respect, the AFM images were processed using Nova Px software and the results were: Ti, $116 \mathrm{~nm} ; \mathrm{Fe}, 90 \mathrm{~nm} ; \mathrm{Pd}, 62 \mathrm{~nm} ; \mathrm{Ag}, 98 \mathrm{~nm}$; and $\mathrm{Au}$, $50 \mathrm{~nm}$. These data were sustained by SEM analysis (figure 5).
The spheroid shapes of nanoparticles were clearly observed in SEM images presented in figure 5. Depending of the nature and the properties of nanoparticles, it can be concluded that the iron and palladium nanoparticles are slightly film-coated. This can be explained by the similarities between both elements (cubic structure, density, covalent radius, etc.).

Therefore, for a complex investigation of nanoparticles adsorption mechanism, the chemical composition of layers 


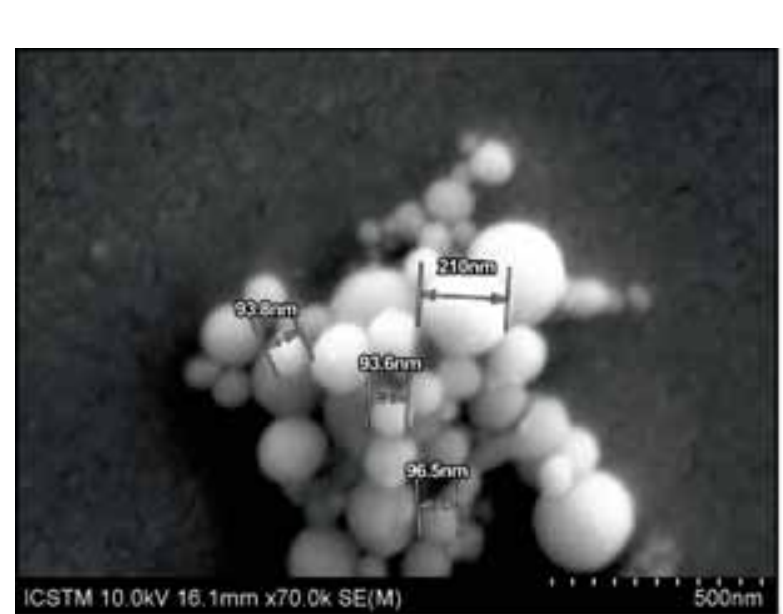

$$
\text { d }
$$
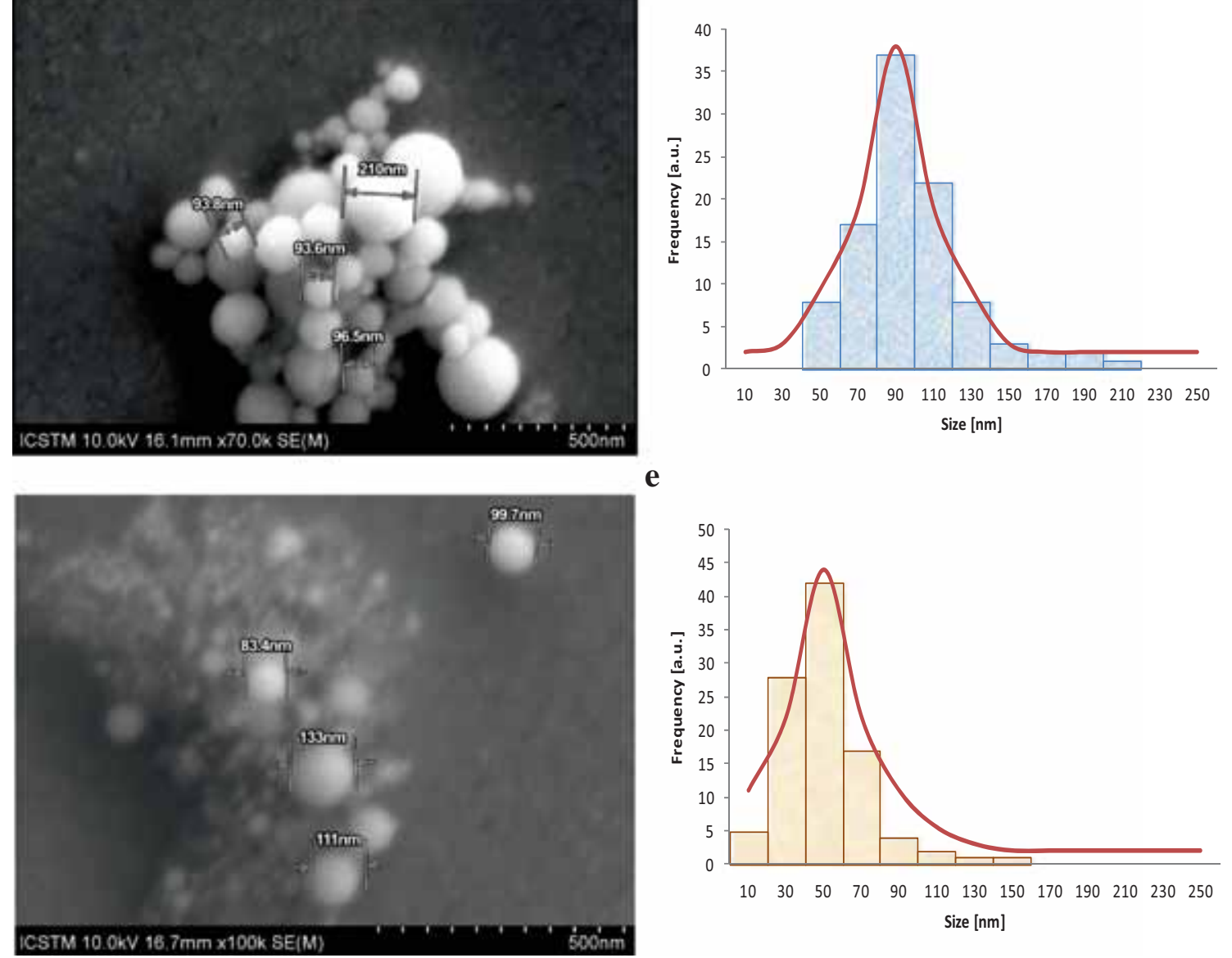

Figure 5. Continued.

Table 2. Elemental concentration of metallic layers determined by SEM-EDS.

\begin{tabular}{lccccr}
\hline & \multicolumn{5}{c}{ Nanoparticles } \\
\cline { 2 - 6 } Elements (\%) & Ti NP & Fe NP & Pd NP & Ag NP & Au NP \\
\hline $\mathrm{C}$ & $13.00 \pm 0.09$ & $11.65 \pm 0.24$ & $6.80 \pm 0.79$ & ND & $10.09 \pm 0.16$ \\
$\mathrm{~N}$ & $\mathrm{ND}$ & $\mathrm{ND}$ & $\mathrm{ND}$ & $\mathrm{ND}$ & $3.06 \pm 0.22$ \\
$\mathrm{O}$ & $16.91 \pm 0.15$ & $22.28 \pm 0.34$ & $8.19 \pm 0.16$ & $4.62 \pm 0.12$ & $8.57 \pm 0.19$ \\
$\mathrm{Na}$ & $3.85 \pm 0.02$ & $\mathrm{ND}$ & $0.45 \pm 0.02$ & $\mathrm{ND}$ & $2.20 \pm 0.04$ \\
$\mathrm{Si}$ & $8.71 \pm 0.03$ & $8.47 \pm 0.07$ & $14.39 \pm 0.05$ & $5.63 \pm 0.05$ & $11.45 \pm 0.06$ \\
$\mathrm{~S}$ & $0.20 \pm 0.03$ & $\mathrm{ND}$ & $0.29 \pm 0.05$ & $\mathrm{ND}$ & $\mathrm{ND}$ \\
$\mathrm{Ti}$ & $4.53 \pm 0.03$ & $2.41 \pm 0.05$ & $3.55 \pm 0.03$ & $2.91 \pm 0.05$ & $3.25 \pm 0.06$ \\
$\mathrm{Ag}$ & $\mathrm{ND}$ & $\mathrm{ND}$ & $\mathrm{ND}$ & $8.19 \pm 0.21$ & $\mathrm{ND}$ \\
$\mathrm{Pd}$ & $\mathrm{ND}$ & $\mathrm{ND}$ & $2.29 \pm 0.07$ & $\mathrm{ND}$ & $\mathrm{ND}$ \\
$\mathrm{Fe}$ & $\mathrm{ND}$ & $4.83 \pm 0.15$ & $\mathrm{ND}$ & $\mathrm{ND}$ & $\mathrm{ND}$ \\
$\mathrm{Pt}$ & $\mathrm{ND}$ & $\mathrm{ND}$ & $\mathrm{ND}$ & $\mathrm{ND}$ & $8.50 \pm 0.51$ \\
$\mathrm{Au}$ & & & & &
\end{tabular}

$\mathrm{ND}=$ not determined

was achieved using SEM coupled with EDX spectrometer. The results are shown in table 2 , where the concentration values for each sample can be observed.
In addition, the expected elements ( $\mathrm{Si}, \mathrm{O}$ from quartz crystal; Ti and Pt from sensor metallization and the nanocolloidal element) have discovered a number of other elements 
such as, N, Na and S, which can appear from atmosphere during the adsorption process. In this case, the presence of these impurities (i.e., $\mathrm{N}, \mathrm{Na}$ and $\mathrm{S}$ ) can affect the quality and uniformity of the self-assembled monolayers (SAM) on these metallic surfaces. Further research will be performed and characterized few types of SAM with different application fields (e.g. pharmaceuticals, medicine, agriculture, food safety, electronics, etc.).

\section{Conclusion}

In this study, four techniques (QCM, AFM, SEM and EDS) were successfully combined to characterize the morphology and adsorption mechanism of different metallic nanoparticles. The main objective of this research was to obtain the nanoparticles' most uniform layers for a further manufacturing deposition processes.

\section{Acknowledgements}

We would like to thank to anonymous reviewers for their remarks and advices.

\section{References}

[1] Schrand A M, Hens S A C and Shenderova O A 2009 Crit. Rev. Solid State Mater. Sci. 3418

[2] Faklaris O, Joshi V, Irinopoulou T, Tauc P, Sennour M, Girard $\mathrm{H}$ et al 2009 ACS Nano 33955

[3] Chow E K, Zhang X Q, Chen M, Lam R, Robinson E, Huang $\mathrm{H}$ et al 2011 Sci. Transl. Med. 3 73ra21

[4] Merkel T J and DeSimone J M 2011 Sci. Transl. Med. 3 73ps8

[5] Phan M H, Alonso J, Khurshid H, Lampen-Kelley P, Chandra S, Stojak Repa K et al 2016 Nanomaterials 6221

[6] Gowda R, Madhunapantula S V, Sharma A, Kuzu O F and Robertson G P 2014 Mol. Cancer Ther. 132328

[7] Mochalin V N, Shenderova O, Ho D and Gogotsi Y 2011 Nat. Nanotechnol. 711

[8] Holt K B 2007 Philos. Trans. R Soc. A 3652845

[9] Kotov N A 2010 Science 330188

[10] Correia Carabineiro S A 2017 Molecules 22857

[11] Zaffran M, Vandelaer J, Kristensen D, Melgaard B, Yadav P, Antwi-Agyei K O et al 2013 Vaccine 31 B73

[12] Chen H W, Huang C Y, Lin S Y, Fang Z S, Hsu C H, Lin J C et al 2016 Biomaterials 106111

[13] Popescu R C and Grumezescu A M 2015 Curr. Top. Med. Chem. 151532

[14] Webster D M, Sundaram P and Byrne M E 2013 Eur. J. Pharm. Biopharm. 841

[15] Hartwell B L, Antunez L, Sullivan B P, Thati S, Sestak J O and Berkland C 2015 J. Pharm. Sci. 104346

[16] Nelson B C, Johnson M E, Walker M L, Riley K R and Sims C M 2016 Antioxidants 515

[17] Pradeep T and Anshup 2009 Thin Solid Films 5176441
[18] He F, Zhao D and Roberts C 2009 In Nanotechnology applications for clean water (eds) N Savage, M Diallo, J Duncan, A Street and R Sustich (USA: William Andrew Publication)

[19] Cao G 2004 Nanostructures and nanomaterials: synthesis, properties and applications (London: Imperial College Press)

[20] Feldheim D L and Foss Jr C A 2002 Metal nanoparticles: synthesis characterization and applications (New York: Marcel Dekker Inc.)

[21] Hipler (Jena) U C and Jena E P 2006 Biofunctional textiles and the skin (Basel: Karger AG)

[22] Kathirvelu S, D'Souza L and Dhurai B 2009 Indian J. Fibre Text. 34267

[23] Radulescu C, Hossu A M, Manea L and Tarabasanu-Mihaila C 2007 Rev. Chim. (Bucharest) 58958

[24] Radulescu C, Ionita I, Moater E I and Gheboianu A 2010 Ind. Text. 61168

[25] Chen C, Li Y, Song J, Yang Z, Kuang Y, Hitz E et al 2017 Adv. Mater. 20171701756

[26] Mane S G, Sawant P R and Shinde N N 2015 Int. Res. J. Eng. Tech. 2703

[27] Gawande M B, Goswami A, Felpin F X, Asefa T, Huang X, Silva R et al 2016 Chem. Rev. 1163722

[28] Gawande M B, Shelke S N, Zboril R and Varma R S 2014 Acc. Chem. Res. 471338

[29] Li G, Li X H and Zhang Z J 2011 Prog. Chem. 231644

[30] Yin G, Nishikawa M, Nosaka Y, Srinivasan N, Atarashi D, Sakai E et al 2015 ACS Nano 92111

[31] Bhanushali S, Ghosh P, Ganesh A and Cheng W 2015 Small 11 1232

[32] Bichler O, Zhao W, Alibart F, Pleutin S, Vuillaume D and Gamrat C 2010 IEEE Trans. Electron Dev. 573115

[33] Noh J S, Lee J M and Lee W 2011 Sensors 11825

[34] Hung C, Lin H, Chen H, Tsai Y, Lai P, Fu S et al 2007 Sens. Actuat. B 12281

[35] Wang G H, Hilgert J, Richter F H, Wang F, Bongard H J, Spliethoff B et al 2014 Nat. Mater. 13293

[36] Bauer J C, Chen X, Liu Q S, Phan T H and Schaak R E 2008 J. Mater. Chem. 18275

[37] Tan C W, Tan K H, Ong Y T, Mohamed A R, Hussein S, Zein S et al 2011 In Environmental chemistry for a sustainable world (eds) E Lichrfouse, J Schwarzbauer and D Robert (DordrechtHeidelberg-London-New York: Springer)

[38] Martirosyan A and Schneider Y J 2014 Int. J. Environ. Res. Public Health 115720

[39] Masdor N A, Altintas Z and Tothill I E 2016 Biosens. Bioelectron. 78328

[40] Maciejewska-Prończuk J, Morga M, Adamczyk Z, Oćwieja M and Zimowska M 2017 Colloids Surf. A 514226

[41] Kananizadeh N, Rice C, Lee J, Rodenhausen K B, Sekora D, Schubert Mathias et al 2017 J. Hazard. Mater. 322118

[42] Chen Q, Xu S, Liu Q, Masliyah J and Xu Z 2016 Adv. Colloid Interface Sci. 23394

[43] Bailey C M, Kamaloo E, Waterman K L, Wang K F, Nagarajan R and Camesano T A 2015 Biophys. Chem. 203-204 51

[44] Eggersdorfer M L and Pratsinis S E 2014 Adv. Powder Technol. 2571

[45] Jiang J, Oberdörster G and Biswas P 2009 J. Nanopart. Res. 1177

[46] Reimhult K, Yoshimatsu K, Risveden K, Chena S, Ye L, Krozera A 2008 Biosens. Bioelectron. 231908 
[47] Cimpoca G V, Radulescu C, Dulama I D, Popescu I V, Stihi C, Gheboianu A et al 2009 AIP Conf. Proc. 1203409

[48] Cimpoca G V, Radulescu C, Dulama I D, Popescu I V, Gheboianu A, Bancuta I et al 2009 AIP Conf. Proc. 1203 160

[49] Cimpoca G V, Radulescu C, Popescu I V, Dulama I D, Ionita, I, Cimpoca M et al 2009 AIP Conf. Proc. 1203415

[50] Cimpoca G V, Popescu I V, Dulama I D, Radulescu C, Bancuta I, Cimpoca M et al 2009 IEEE Proc. CAS Conf. 1-2 135

[51] Dulama ID, Popescu I V, Cimpoca G V, Radulescu C, Bucurica I A, Let D et al 2013 IEEE Proc. CAS Conf. 1-2 107

[52] Sauerbrey G 1959 Z. Phys. 155206
[53] Long C J and Cannara R J 2015 Rev. Sci. Instrum. 86073703

[54] Let D, Bucurica A, Dulama I, Bacinschi Z, Mihai S and Filip V 2015 Sci. Bull. Mater. Mech. 1071

[55] Negrea A, Bacinschi Z, Bucurica I A, Teodorescu S and Stirbescu R 2016 Rom. J. Phys. 61527

[56] Radulescu C, Stihi C, Popescu I V, Varaticeanu B, Telipan G, Bumbac M et al 2016 J. Sci. Arts 177

[57] Teodorescu S, Ion R M, Nechifor G, Bucurica I A, Dulama I D, Stirbescu R M et al 2017 Rev. Chim. (Bucharest) 68869

[58] Bintintan A, Gligor M, Dulama I D, Teodorescu S, Stirbescu R M and Radulescu C 2017 Rev. Chim. (Bucharest) 68 847 